\title{
FAMILY SUPPORT-BASED PSYCHOEDUCATION IN CARING SCHIZOPHRENIC PATIENTS: A LITERATURE REVIEW
}

\author{
Dwi Indah Iswanti ${ }^{1}$, Moses Glorino Rumambo Pandin ${ }^{2}$ \\ ${ }^{1}$ Student of Doctoral Program in Nursing, Faculty of Nursing, Universitas Airlangga \\ ${ }^{2}$ Faculty of Humanities, Universitas Airlangga \\ Email: dwi.indah.iswanti-2021@fkp.unair.ac.id; moses.glorino@fib.unair.ac.id
}

\begin{abstract}
Background: The burden of family in caring a schizophrenia impacts on psychological shock and emotional burden; lack of disease knowledge and care skills; poor patient medication adherence; the difficulty of getting along with patients; conflict in the family or at work; financial burden; and need adequate social support.

Aim: This study discussed how family support takes care of people with schizophrenia with a psychoeducational approach in mental health service settings.

Method: A non-systematic literature review was carried out using the PICO (Population, Intervention, Comparison, Outcome) framework utilizing Scopus, CINAHL, and ProQuest databases in the last 5 years, searching with keywords "Family Support AND Schizophrenia OR Family Psychoeducation".

Results: Families with schizophrenia experience the most potent stressors on the burden of care borne, in addition to stigma and the frequency of relapse of sufferers. Community care providers can involve the family in various ways, such as providing psychoeducation, supporting the family's physical, emotional and social needs, and behavioral family assessment or family therapy.

Conclusion: Mental health services must develop and imply family psychoeducation training.
\end{abstract}

Key words: Family Support, Psychoeducation, Schizophrenia

Corresponding Author: *Dwi Indah Iswanti, Student of Doctoral Program in Nursing, Faculty of Nursing, Airlangga University, Email: dwi.indah.iswanti-2021@fkp.unair.ac.id Tel. $(+62) 81325758841$

\section{INTRODUCTION}

Schizophrenia is a chronic disease that requires long-term care. Barriers that families often encounter in caring for schizophrenia include isolation of patients from daily life, incomplete recovery, lack of support by the mental health care system, and stigmatization. ${ }^{1}$ The barriers make burden for the family causing psychological shock and emotional burden; lack of disease knowledge and care skills; poor medication adherence from the patient; difficulty to get along with patients; conflict in the family or at work; financial burden; and require sufficient social support. ${ }^{2}$ This makes the family experience stress triggered by the limitations of the adequacy of the family structure and function, which will inhibit the family from using other resources and create family stress. ${ }^{3}$

The prevalence of schizophrenia in the world globally is more than 20 million people, there are $69 \%$, and even more in the world, people with schizophrenia do not get appropriate services. $90 \%$ of people with schizophrenia undergo treatment and are in developing 
countries where the community's income level is in the middle to low range. The problem is that families with schizophrenia have less access to mental health services, then, schizophrenia often requires treatment compared to other chronic diseases. ${ }^{4}$ Mental disorders are a significant public health problem and rank among the top 10 causes of the global disease burden. ${ }^{5}$ The prevalence of Schizophrenia in Indonesia was 7 cases per mile in 2018 (an increase of $0.18 \%)^{6}$

Families caring for schizophrenia will experience a parenting burden, where primary family caregivers experience a burden from mild to moderate levels and have a poor quality of life. The caregiver's age and the condition of not having a job add to caregivers' burden for people with schizophrenia. In addition, the family burden is also increased by difficulties in caring for sufferers with severe psychiatric symptoms, decreased cohabitation, and low family coping strategies that lead to poor quality of life. ${ }^{5}$ Family-focused interventions for institutionalized caregivers of people with schizophrenia that include psychological support and peer support groups are recommended to improve mutuality and family coping strategies, reduce caregiver burden, and improve caregiver quality of life.. ${ }^{5}$ Thus, this literature review discusses family support through psychoeducation to lessen the burden of parenting and increase the capacity of families in treating schizophrenia.

\section{METHOD}

Briefly, to obtain the evidence regarding the psychoeducation used by family as a support for caring the schizophrenia patients, we first identified published, peer-reviewed research articles using a non-systematic search across several databases. After processing eligible studies, we identified and obtained primary studies from these published research papers to generate the compendium of papers about psychoeducation used by family as a support for caring the schizophrenia patients. We developed a narrative summary and a thematic synthesis to synthesize the quantitative and qualitative data, respectively. We conducted third synthesis to combine the previous two syntheses. No protocol existed for this literature review. This research did not involve participation of human subjects, thus research ethics board review was not required, nor was informed consent.

\section{Search strategy and inclusion criteria for literature reviews}

The literature review was performed using the PICO Literature Review (Table 1) framework within ScienceDirect, ProQuest, SAGE, DOAJ (Directory of Open Access Journals)databases in the last 5 years, with keywords Family Support AND Schizophrenia OR Family Psychoeducation. In addition, to get many references, researchers also use synonyms in searching literature such as mental illness and mental health. Reviews were also carried out on abstracts and references from articles collected.

After getting 20 eligible articles, the primary substance is identified and generalized as a psychoeducation-based family support theme.

Titles and abstract of manuscript were assessed for relevance to the topic using the following inclusion criteria:

1. The research design used quantitative, qualitative and Random Control Trial (RCT) published from 2017-2021 in English

2. Research respondents diagnosed with schizophrenia

3. The intervention approach used were in the form of family support and psychoeducation

4. Family support for treating schizophrenic patients with a psychoeducational approach was described 
Table 1. Description of PICO Literature Review

\begin{tabular}{cll}
\hline P & Patient, Population, Problem & Schizophrenia, Mental illness \\
\hline I & Intervention & $\begin{array}{l}\text { Family support, Family } \\
\text { Psychoeducation }\end{array}$ \\
\hline $\mathrm{C}$ & $\begin{array}{l}\text { Comparison Intervention (if } \\
\text { appropriate) }\end{array}$ & NA \\
\hline $\mathrm{O}$ & $\begin{array}{l}\text { Outcome to Measure or } \\
\text { Achieve }\end{array}$ & Treatment in schizophrenia \\
\hline $\mathrm{S}$ & Study design & $\begin{array}{l}\text { Quantitative, Qualitative and } \\
\text { Random Control Trial }\end{array}$ \\
\hline
\end{tabular}

If relevance was not apparent based on the initial review, the full article was read to determine whether it should be included. After the initial group of articles was collected, 59 full-text articles were read to ensure final inclusion in the review. 20 articles met the inclusion criteria. Data were extracted into the JCR to review the study characteristics and the level of evidence level for each article. There were 5 articles as the evidence base of this study, 15 as professional standards, and 5 (recommendations) were not included in this study, because the purpose of this review was to investigate the original empirical studies. We focus on articles that highlight family support providing care for schizophrenia with a psychoeducational approach in primary mental health care.

\section{Study Selection, Data extraction and Management}

From each full-text, we collected the data about the publication year, the databases searched, the study population, and the environment modifications. The authors independently screened titles, abstract, and full texts of articles. The authors retrieved full-text versions of potential articles and determined final inclusion in the review on the basis of relevance to the question, study quality, level of evidence, and inclusion and exclusion criteria. Disagreements were resolved by discussion or by consulting another author if necessary.

Each retained article was appraised and key information extracted to an evidence table that provide a summary of the methods and findings of the article. Supplemental table summarizes the characteristics, including methodology, environmental modification assessed, result, and recommendation.

\section{Risk of bias assessment and grading the quality of evidence}

The risk of bias of each study was not evaluated. The overall quality of evidence was not assessed. Results regarding the risk of bias and grading the quality were resolved through discussion.

\section{Outcome measures}

We focused on articles that considered psychoeducation as family support in caring patients with schizophrenia. 
medRxiv preprint doi: https://doi.org/10.1101/2022.01.11.22268923; this version posted January 14, 2022. The copyright holder for this preprint (which was not certified by peer review) is the author/funder, who has granted medRxiv a license to display the preprint in perpetuity.

All rights reserved. No reuse allowed without permission.

\section{RESULT AND DISCUSION}

\section{Study selection}

A total of 59 citations and abstracts were screened during the initial search. 29 records were excluded in the abstract review and 20 were assessed in full-text and following full-text review and ultimately, then eight studies were included in the final analysis (Figure 1).
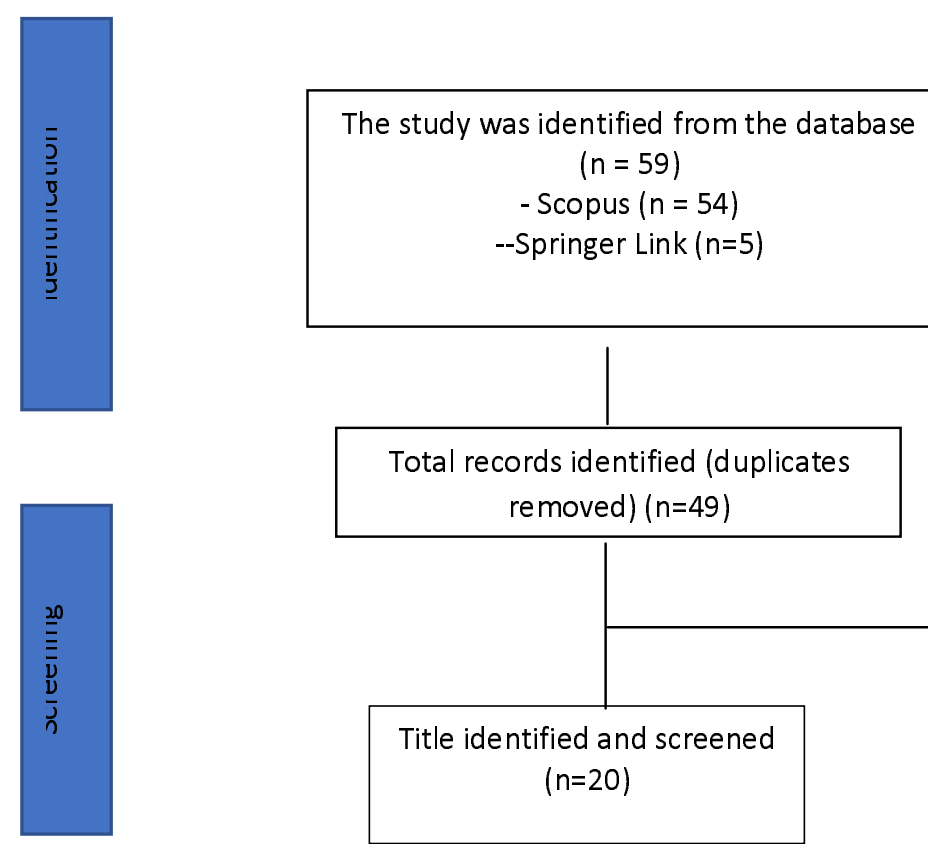

Total records identified (duplicates removed) $(n=49)$
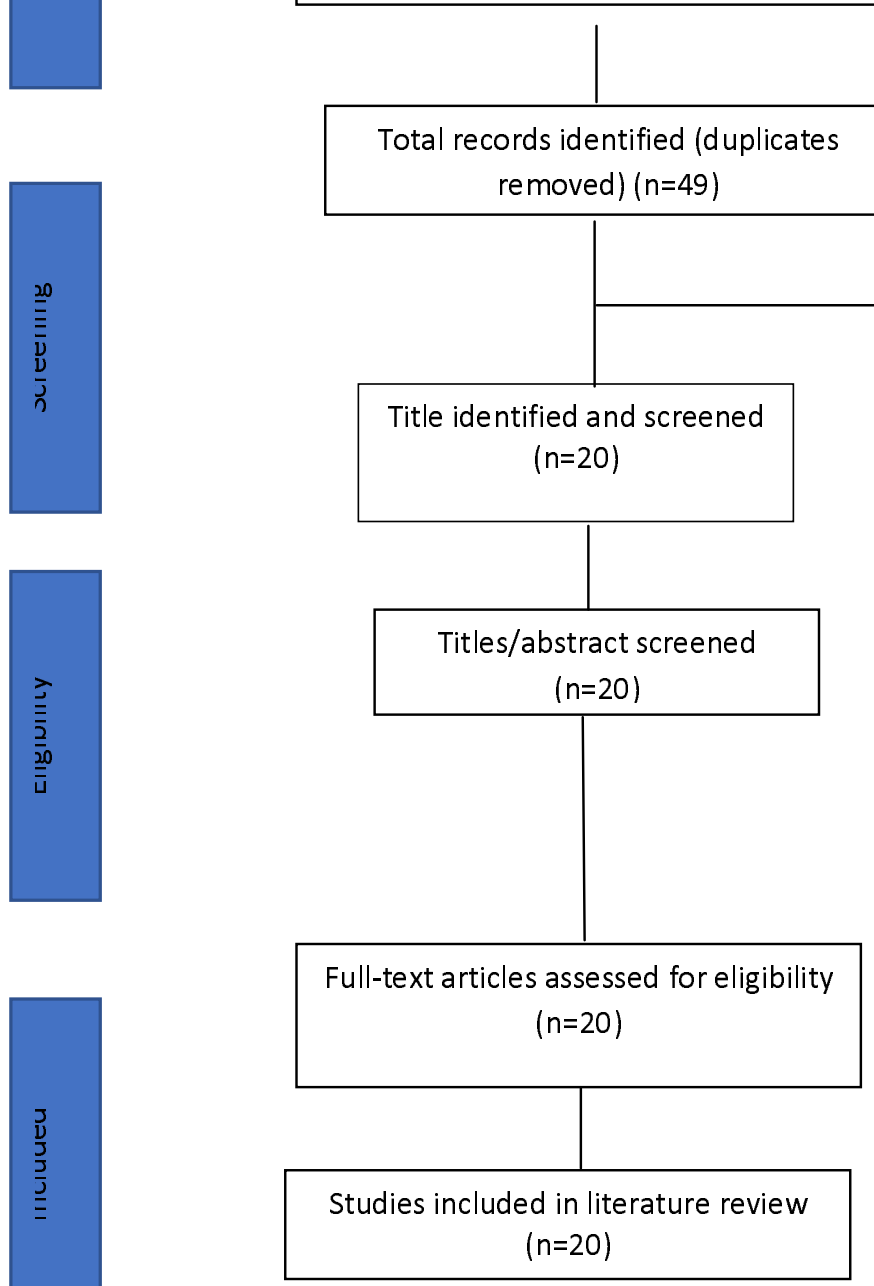

Figure 1. PRISMA Flow Diagram of Included Studies 
Articles review

\begin{tabular}{|c|c|c|c|}
\hline No. & $\begin{array}{c}\text { Title, Researcher and } \\
\text { Year }\end{array}$ & Methodology & Results \\
\hline 1. & $\begin{array}{lr}\text { Predictors of } & \text { Family } \\
\text { Stress in Taking } & \text { Care of } \\
\text { Patients } & \text { with } \\
\text { Schizophrenian. }^{3} & \end{array}$ & $\begin{array}{l}\text { Design: } \\
\text { design } \\
\text { Sample: } \\
\text { sampling } \\
\text { Variable: Family families } \\
\text { family stress, care burden, } \\
\text { stigma, recurrence } \\
\text { Instrument: Caregiver } \\
\text { Strain Index questionnaire } \\
\text { stigma's dimension Social } \\
\text { Support Index. Brief } \\
\text { Psychiatry Rating Scale } \\
\text { Symptom Rating Test } \\
\text { (Kellner \& Sheffield, } \\
\text { 1973) } \\
\text { Analysis: }\end{array}$ & $\begin{array}{l}\text { Family stress was predicted } \\
\text { by family structure } \\
(\mathrm{p}=0.029) \text { stigma } \\
(\mathrm{p}=0.000) \text {, burden of care } \\
(\mathrm{p}=0.000) \text { and patient } \\
\text { relapse frequency ( } \mathrm{p}=0.000) \\
\mathrm{p}=0.005) \text {. Care burden was } \\
\text { the strongest predictor of } \\
\text { family stress (Beta }=0.619) \text {. } \\
\text { Relapse frequency and } \\
\text { patient stigma are other } \\
\text { types of family stressors. } \\
\text { Stressors stimulate negative } \\
\text { perceptions, which are } \\
\text { called load treatment. The } \\
\text { limited adequacy of family } \\
\text { structure-function will } \\
\text { hinder the family in using } \\
\text { other resources, creating } \\
\text { family stress. }\end{array}$ \\
\hline 2. & $\begin{array}{l}\text { Determinants of family } \\
\text { independence in caring } \\
\text { for hebephrenic } \\
\text { schizophrenia patients. }\end{array}$ & $\begin{array}{l}\text { Design: cross-sectional } \\
\text { Sample: } 57 \text { respondents } \\
\text { Variables: knowledge, } \\
\text { perception, attitude, and } \\
\text { support, while } \\
\text { independence is the } \\
\text { dependent variable, } \\
\text { instrument: questionnaire } \\
\text { analysis: test Spearman's } \\
\text { rank }\end{array}$ & $\begin{array}{l}\text { There is a relationship } \\
\text { between knowledge, } \\
\text { perception, attitude, and } \\
\text { support and Family } \\
\text { independence in treating } \\
\text { hebephrenic schizophrenia. } \\
\text { In } \\
\text { addition, the Spearman's } \\
\text { rank test showed P values of } \\
0.008 \text {, 0.011, 0.032, and } \\
0.027 \text { on family knowledge, } \\
\text { perceptions, attitudes and } \\
\text { support, respectively, at } \\
<0.05 \text {. } \\
\text { Conclusion: This study } \\
\text { shows the importance of } \\
\text { family support in an effort } \\
\text { to increase self-esteem of } \\
\text { schizophrenic patients. } \\
\text { Based on these data, it is } \\
\text { expected that hospitals can } \\
\text { develop a family-based } \\
\text { patient recovery program. }\end{array}$ \\
\hline 3. & $\begin{array}{lrr}\text { Levels of stress } & \text { and } \\
\text { coping } & \text { strategies } & \text { in }\end{array}$ & $\begin{array}{l}\text { Design: cross-sectional } \\
\text { Sample: } 87 \text { families }\end{array}$ & $\begin{array}{l}\text { Stress level was not } \\
\text { significantly associated with }\end{array}$ \\
\hline
\end{tabular}


family caregivers who Variable: knowing the treat schizophrenic relationship between stress patients with risk of levels and coping violent behavior. ${ }^{8}$

strategies of family caregivers who care for

schizophrenia patients

with the risk of violent

behavior

Instruments: Perceived

Stress Scale (PSS) and

Ways of Coping (WOC)

questionnaires).

Analysis: chi-square

4. The experiences
Turkish families ca
for individuals
Schizophrenia:
qualitative inquiry. ${ }^{9}$

coping strategies in family caregivers. Conclusion: Good support from health professionals and social services is needed to help family caregivers cope well with their stressors.

Learning and accepting disorders, nurturing, social dimensions and dimensions of service. Families have problems accepting these orders and upbringing affects their quality of life both financially and socially. Since schizophrenia is one of the f Design: qualitative

Sample: 31 members and with 12 families

A Variables: personal burden social support that affect families providing care to individuals schizophrenia Instruments: interviews Analysis: thematic with in-depth and coping strategies, and reasons for being isolated from the community, the family prefers to hide it. Although families are satisfied with the community-based system, they need long-term solutions, training and financial assistance. Conclusion: To reduce the burden, family therapy, education and psychological support should be provided to families, and employment opportunities, long-term care services and psychological support should be provided for individuals with schizophrenia.

5. Mental health and Design: RCT caregiving experiences Sample: 407 families of family carer supporting people with psychosis. $^{10}$
Variable: relationship between demographics, parenting characteristics and mental health outcomes in family
Care giver of people with psychosis has worse mental health than non-caregivers. Partners, single caregivers and those who spent more than 35 hours per week caring were found to be 


\begin{tabular}{|c|c|c|c|}
\hline & & $\begin{array}{l}\text { caregivers who support } \\
\text { individuals with psychosis } \\
\text { and compare caregiver } \\
\text { outcomes with general } \\
\text { population norms } \\
\text { Instrument: Mental Well- } \\
\text { Being Scale Well-being, } \\
\text { Experience of Caregiving } \\
\text { Inventory, Quality of life } \\
\text { using EQ-5D-5L } \\
\text { Analysis: meta-analysis }\end{array}$ & $\begin{array}{l}\text { most at risk for poor mental } \\
\text { health. Suggestion: to } \\
\text { develop predictive models } \\
\text { to determine risk factors, } \\
\text { therefore to assist in early } \\
\text { identification of caregiver } \\
\text { support needs. Such } \\
\text { understanding is also useful } \\
\text { for informing the } \\
\text { development of tailored } \\
\text { interventions. }\end{array}$ \\
\hline 6. & $\begin{array}{l}\text { Caregiver burden and } \\
\text { health-related quality of } \\
\text { life among primary } \\
\text { family caregivers of } \\
\text { individuals } \\
\text { schizophrenia: a cross- } \\
\text { sectional study. }\end{array}$ & $\begin{array}{l}\text { Design: Cross-sectional } \\
\text { Sample: } 157 \text { families } \\
\text { Variable: relationship } \\
\text { between caregiver burden } \\
\text { and health-related quality } \\
\text { of life (HRQoL) among } \\
\text { primary family caregivers } \\
\text { of individuals with } \\
\text { schizophrenia } \\
\text { Instrument: } \\
\text { demographic socio- } \\
\text { questionnaire and clinical } \\
\text { information, Scale } \\
\text { Mutuality, Family Crisis- } \\
\text { Oriented Personal } \\
\text { Evaluation Scale, Zarit } \\
\text { Burden Interview, and } \\
\text { World Health } \\
\text { Organization abridged } \\
\text { version of Quality of Life. } \\
\text { Analysis: descriptive, } \\
\text { independent t test, Pearson } \\
\text { correlation, one-way } \\
\text { analysis of variance, } \\
\text { multiple regression, }\end{array}$ & $\begin{array}{l}\text { Primary caregivers } \\
\text { experienced mild to } \\
\text { moderate caregiver burden } \\
\text { and poor HRQoL. Primary } \\
\text { caregivers who were older } \\
\text { and unemployed, cared for } \\
\text { patients with severe } \\
\text { psychiatric symptoms, and } \\
\text { had lower monthly incomes, } \\
\text { decreased cohabitation, and } \\
\text { fewer family coping } \\
\text { strategies were associated } \\
\text { with greater caregiver } \\
\text { burden and poor HRQoL. } \\
\text { Greater family mutuality } \\
\text { and coping strategies of } \\
\text { reframing and seeking } \\
\text { spiritual support were the } \\
\text { most significant factors in } \\
\text { increasing caregiver burden } \\
\text { and all HRQoL domains. } \\
\text { Family-focused } \\
\text { interventions } \\
\text { institutionalized caregivers } \\
\text { of people } \\
\text { schizophrenia that include } \\
\text { psychological support and } \\
\text { peer support groups are } \\
\text { recommended to improve } \\
\text { mutuality and family coping } \\
\text { strategies, reduce caregiver } \\
\text { burden, and improve } \\
\text { HRQoL. }\end{array}$ \\
\hline $1-$ & $\begin{array}{l}\text { Challenge of parents } \\
\text { caring for children or } \\
\text { adolescents with early- } \\
\text { stage schizophrenia in } \\
\text { China: A qualitative } \\
\text { study. }^{2}\end{array}$ & $\begin{array}{l}\text { Design: qualitative } \\
\text { Sample: } 13 \text { parents } \\
\text { Variable: challenges of } \\
\text { parents caring for } \\
\text { children/adolescents with } \\
\text { early stage schizophrenia }\end{array}$ & $\begin{array}{l}\text { Psychological shock and } \\
\text { emotional burden; lack of } \\
\text { disease knowledge and care } \\
\text { skills; poor patient } \\
\text { medication adherence; } \\
\text { difficulty getting along with }\end{array}$ \\
\hline
\end{tabular}




\begin{tabular}{|c|c|c|c|}
\hline & & $\begin{array}{l}\text { Instrument: in-depth } \\
\text { interview } \\
\text { Analysis: thematic }\end{array}$ & $\begin{array}{l}\text { patients; conflict in the } \\
\text { family or at work; financial } \\
\text { burden; and need adequate } \\
\text { social support. Each } \\
\text { challenge is produced and } \\
\text { influenced under the } \\
\text { specific social context of } \\
\text { China. } \\
\text { Practice Implications: } \\
\text { Professional support is } \\
\text { needed to help patients with } \\
\text { schizophrenia to cope with } \\
\text { their situation promptly. } \\
\text { Educational initiatives } \\
\text { should focus on mental } \\
\text { health to prevent } \\
\text { discrimination from society } \\
\text { and enable people to } \\
\text { recognize early symptoms } \\
\text { of schizophrenia in children }\end{array}$ \\
\hline & $\begin{array}{lr}\text { Evaluating } & \text { the } \\
\text { effectiveness of a } \\
\text { culturally } \\
\text { behavioral adapted } \\
\text { psycho-educational } \\
\text { program for Egyptian } \\
\text { patients } \\
\text { schizophrenia. }\end{array}$ & $\begin{array}{l}\text { Design: prospective } \\
\text { randomized control } \\
\text { Sample: } 30 \text { patients and } \\
\text { their families } \\
\text { Variables: adapted the } \\
\text { Behavioral Family } \\
\text { Psycho-Education } \\
\text { Program (BFPEP) and } \\
\text { conducted an initial } \\
\text { efficacy evaluation for } \\
\text { outpatients with } \\
\text { schizophrenia } \\
\text { Instrument: Structured } \\
\text { Clinical Interview for } \\
\text { DSM-IV, The Positive and } \\
\text { Negative Syndrome Scale } \\
\text { (PANSS), The Social } \\
\text { Functioning Questionnaire } \\
\text { (SFQ), Quality of Life } \\
\text { scale (QLS), Drug } \\
\text { Attitude Inventory (DAI) }\end{array}$ & $\begin{array}{l}\text { The CA-BFPEP group } \\
\text { showed a significant } \\
\text { treatment effect because } \\
\text { they had a greater reduction } \\
\text { in psychotic symptoms } \\
\text { (PANSS), improved social } \\
\text { functioning (SFQ), quality } \\
\text { of life (QoL), and attitudes } \\
\text { toward medication (DAI), } \\
\text { compared with patients in } \\
\text { the control group. Maximize } \\
\text { the benefits of family } \\
\text { therapy interventions } \\
\text { internationally and to } \\
\text { encourage mental health } \\
\text { policy makers to integrate } \\
\text { these modes of therapy in } \\
\text { routine care management } \\
\text { plans for patients with } \\
\text { schizophrenia. }\end{array}$ \\
\hline & $\begin{array}{l}\text { Barriers to Family } \\
\text { Caregivers' } \\
\text { Coping With Patients } \\
\text { with Severe } \\
\text { Mental Illness in Iran } \\
\text { Hossein Ebrahimi. }\end{array}$ & $\begin{array}{l}\text { Design: qualitative } \\
\text { Sample: } 16 \text { families } \\
\text { purposive sampling } \\
\text { Variable: barriers that } \\
\text { hinder the ability of } \\
\text { families to cope with their } \\
\text { relatives diagnosed with } \\
\text { severe mental illness } \\
\text { Instrument: semi- }\end{array}$ & $\begin{array}{l}\text { Isolation of patients from } \\
\text { daily life days, incomplete } \\
\text { recovery, lack of support by } \\
\text { the mental health care } \\
\text { system, and stigmatization. } \\
\text { Findings on the need to } \\
\text { provide support for } \\
\text { caregivers by a mental } \\
\text { health care delivery service }\end{array}$ \\
\hline
\end{tabular}




\begin{tabular}{|c|c|c|c|}
\hline & & $\begin{array}{l}\text { structured interviews } \\
\text { Analysis: conventional } \\
\text { content analytic }\end{array}$ & system \\
\hline 10. & $\begin{array}{l}\text { Development of a } \\
\text { 22q11DS psycho- } \\
\text { educational program: } \\
\text { exploration of the views, } \\
\text { concerns and educational } \\
\text { needs of parents caring } \\
\text { for children or } \\
\text { adolescents with } \\
\text { 22q11DS in relation to } \\
\text { mental health issues. }\end{array}$ & $\begin{array}{l}\text { Design; Qualitative } \\
\text { Sample: } 22 \text { families } \\
\text { Variables: experience of } \\
\text { parents caring for a child } \\
\text { with 22q11DS, } \\
\text { investigating their } \\
\text { knowledge of the risk of } \\
\text { MH problems and } \\
\text { assessing the need for } \\
\text { psycho-educational } \\
\text { programs } \\
\text { Instrument } \\
\text { Analysis: burnard method }\end{array}$ & $\begin{array}{l}\text { Most parents have } \\
\text { knowledge of the } \\
\text { relationship between } \\
\text { 22q11DS and increased risk } \\
\text { of MH problems. Parents } \\
\text { reported that MH } \\
\text { information relating to } \\
\text { 22q11DS was mainly } \\
\text { obtained from the 22q11DS } \\
\text { conference, the '22q11 } \\
\text { Ireland' support group and } \\
\text { the Internet. Parents } \\
\text { expressed a need for } \\
\text { information to prevent or } \\
\text { treat their child's MH } \\
\text { problems. Parents suggested } \\
\text { that the following topics } \\
\text { would be very useful in } \\
\text { psycho-educational } \\
\text { programs. This includes } \\
\text { information about the early } \\
\text { warning signs of MH } \\
\text { problems and guidance on } \\
\text { when and how to tell a child } \\
\text { about the condition and how } \\
\text { to manage a child or teen's } \\
\text { anxiety, obsessive behavior } \\
\text { or hearing voices. } \\
\text { Conclusion: The findings } \\
\text { indicate parental support for } \\
\text { a psycho-educational } \\
\text { program that will provide } \\
\text { relevant, accurate and } \\
\text { timely information on how } \\
\text { to effectively care for a } \\
\text { child with needs }\end{array}$ \\
\hline 11. & $\begin{array}{l}\text { Experiences of caring for } \\
\text { a sibling with } \\
\text { schizophrenia in a } \\
\text { Chinese context: A } \\
\text { neglected issue. }\end{array}$ & $\begin{array}{l}\text { Design: qualitative } \\
\text { Sample: } 10 \text { sibling } \\
\text { caregivers } \\
\text { Variable: experience of } \\
\text { being the primary } \\
\text { caregiver of a sibling with } \\
\text { schizophrenia } \\
\text { Instrument: } \\
\text { structured interview semi- } \\
\text { Analysis: content analysis }\end{array}$ & $\begin{array}{l}\text { Stepping forward to become } \\
\text { a caregiver; (ii) parenting } \\
\text { challenges; (iii) the need for } \\
\text { support; and (iv) concerns } \\
\text { about future care. Our } \\
\text { findings suggest that mental } \\
\text { health care professionals } \\
\text { should involve all family } \\
\text { members, including } \\
\text { siblings, in treatment plans } \\
\text { for people with }\end{array}$ \\
\hline
\end{tabular}




\begin{tabular}{|c|c|c|c|}
\hline & & & $\begin{array}{l}\text { schizophrenia, and provide } \\
\text { appropriate } \\
\text { psychoeducation for all } \\
\text { family members to reduce } \\
\text { not only current parenting } \\
\text { tensions and stress, but also } \\
\text { anxiety about care in the } \\
\text { future. }\end{array}$ \\
\hline 12. & $\begin{array}{l}\text { Schizophrenia: } \text { Impact }^{15} \\
\text { on Family Dynamics. }\end{array}$ & $\begin{array}{l}\text { Systematic review and a } \\
\text { review of the theory of }\end{array}$ & $\begin{array}{l}\text { intervention families (FI) } \\
\text { for schizophrenia consist of } \\
\text { a combination of strategies } \\
\text { of psychotherapy that aims } \\
\text { to develop a working } \\
\text { relationship between the } \\
\text { family and the medical team } \\
\text { to support the recovery of } \\
\text { the patient showed that } \\
\text { family intervention for } \\
\text { people with impaired } \\
\text { schizophrenia spectrum can } \\
\text { prevent relapse and } \\
\text { hospitalization, improve } \\
\text { medication adherence, } \\
\text { maintain satisfying family } \\
\text { interactions, and have a } \\
\text { positive impact on patients } \\
\text { and relatives' quality of life. } \\
\text { FI usually includes } \\
\text { psychoeducation, stress } \\
\text { management, emotion, } \\
\text { processing, assertive } \\
\text { communication, cognitive } \\
\text { reassessment, and structured } \\
\text { problem solving proven to } \\
\text { be effective in improving } \\
\text { symptomatology, disease } \\
\text { awareness, and satisfaction } \\
\text { levels in patients and } \\
\text { relatives }\end{array}$ \\
\hline & $\begin{array}{l}\text { Economic cost and } \\
\text { quality of life of family } \\
\text { caregivers } \\
\text { schizophrenic patients } \\
\text { attending psychiatric } \\
\text { hospitals in Ghana. }\end{array}$ & $\begin{array}{l}\text { Design: Cross-sectional } \\
\text { samples: } 442 \text { family } \\
\text { variables: the economic } \\
\text { costs and quality of life of } \\
\text { schizophrenia } \\
\text { Instruments: Quality of } \\
\text { Life (WHOQOL-BREF), } \\
\text { Zarit Burden Interview } \\
\text { (ZBI). } \\
\begin{array}{lr}\text { Analysis: } & \text { multiple } \\
\text { regression } & \text { and }\end{array}\end{array}$ & $\begin{array}{l}\text { High house hold burden for } \\
\text { persons living with } \\
\text { schizophrenia in low- } \\
\text { income settings. The results } \\
\text { underscore the need for } \\
\text { policies and programs to } \\
\text { support caregivers. }\end{array}$ \\
\hline
\end{tabular}




\begin{tabular}{|c|c|c|c|}
\hline & & QoLcaregiving & \\
\hline 14. & $\begin{array}{lr}\text { Living } & \text { with } \\
\text { schizophrenia: Health } \\
\text { related quality of life } \\
\text { among primary family } \\
\text { caregivers. }{ }^{17}\end{array}$ & 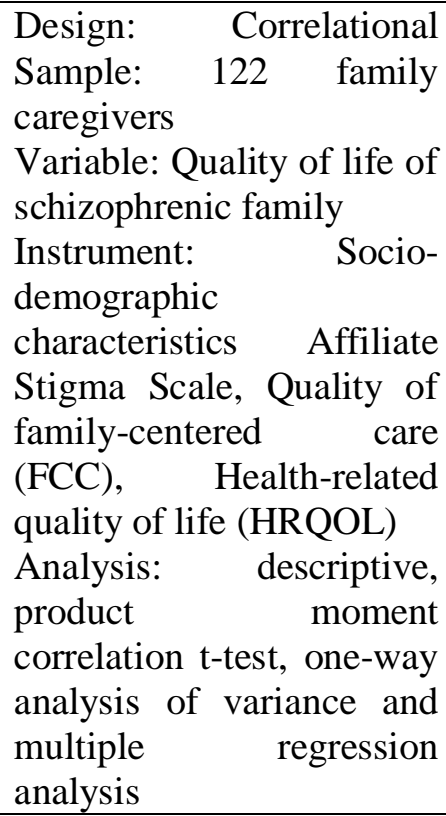 & $\begin{array}{l}\text { Low income, stigma, and } \\
\text { quality of family care are } \\
\text { critical determinants of } \\
\text { health-related quality of life, } \\
\text { so efforts to increase life } \\
\text { satisfaction focus on } \\
\text { reducing stigma, increasing } \\
\text { income. family and } \\
\text { strengthen the quality of } \\
\text { family-centered care }\end{array}$ \\
\hline 15. & $\begin{array}{l}\text { The influence of } \\
\text { psychoeducation on } \\
\text { family's emotional } \\
\text { expressions in caring } \\
\text { patients with paranoid } \\
\text { schizophrenia. }\end{array}$ & $\begin{array}{l}\text { Design: } \\
\text { study } \\
\text { Sample: } 84 \text { families with } \\
\text { random allocation } \\
\text { sampling. } \\
\text { Variables: } \\
\text { Psychoeducation, } \\
\text { emotional expression } \\
\text { Instrument: Emotional } \\
\text { Expressivity Scale (EES) } \\
\text { Analysis: ANOVA were } \\
\text { used to analyze the pre- } \\
\text { post data. }\end{array}$ & 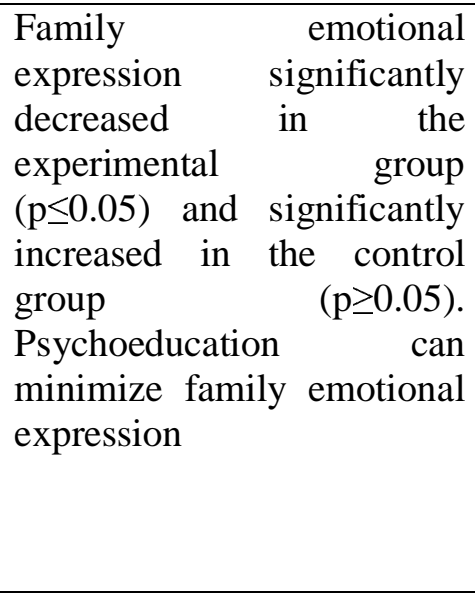 \\
\hline 16. & $\begin{array}{l}\text { Development of a family } \\
\text { resilience model to care } \\
\text { of patients with } \\
\text { schizophrenia. }{ }^{19}\end{array}$ & 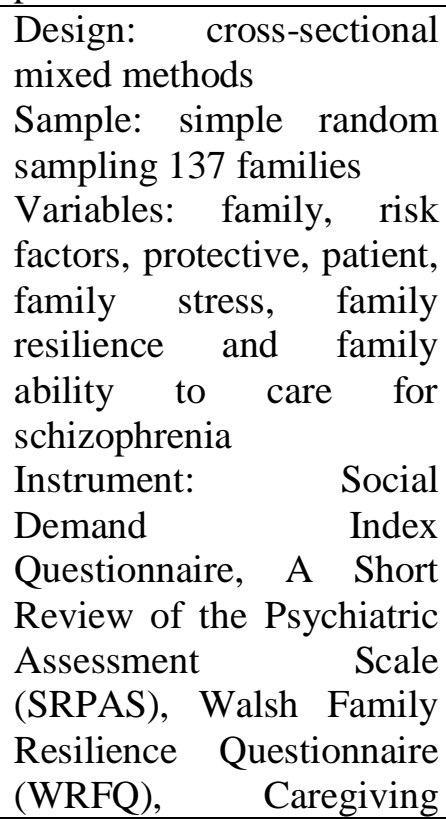 & $\begin{array}{l}\text { The family resilience model } \\
\text { increases family capability } \\
\text { by } 13.4 \% \text {. The model helps } \\
\text { families through stress } \\
\text { management to manage } \\
\text { family burdens and the } \\
\text { impact of stigma so that } \\
\text { families have resilience, use } \\
\text { strength and optimize } \\
\text { family functions in caring } \\
\text { for people with } \\
\text { schizophrenia. }\end{array}$ \\
\hline
\end{tabular}




\begin{tabular}{|c|c|c|c|}
\hline & & $\begin{array}{l}\text { Tasks in Caring for an } \\
\text { Adult with Mental Illness } \\
\text { Scale (CTiCAMIS) and } \\
\text { the Barthel Index } \\
\text { questionnaire, } \\
\text { Analysis: SEM-PLS }\end{array}$ & \\
\hline 17. & $\begin{array}{l}\text { Effect of Strengthening } \\
\text { Family } \\
\text { Resources on Emotion } \\
\text { Regulation of Family } \\
\text { Caregivers of Patients } \\
\text { with Schizophrenia. }\end{array}$ & $\begin{array}{l}\text { Design: quasi } \\
\text { experimental } \\
\text { Sample: } 29 \text { interventions, } \\
31 \text { control group } \\
\text { Variables: family coping, } \\
\text { emotional regulation } \\
\text { Instrument: Emotion } \\
\text { Regulation Questionnaire } \\
\text { Analysis: independent and } \\
\text { paired t-test for }\end{array}$ & $\begin{array}{l}\text { Strengthening family coping } \\
\text { resources (SFCR) This } \\
\text { intervention can guide } \\
\text { doctors on how to } \\
\text { implement a treatment } \\
\text { program family-centered } \\
\text { approach to reduce the } \\
\text { burden of caring for } \\
\text { schizophrenic patients } \\
\text { through obtaining family } \\
\text { support in the efficient care } \\
\text { of these patients. }\end{array}$ \\
\hline 18. & $\begin{array}{l}\text { Family care for persons } \\
\text { with severe mental } \\
\text { illness: experiences and } \\
\text { perspectives of } \\
\text { caregivers in Uganda. }\end{array}$ & $\begin{array}{l}\text { Design: Phenomenology } \\
\text { Sample: } 10 \text { focus groups } \\
\text { of patient caregivers } \\
\text { Variable: experience of } \\
\text { caring for family members } \\
\text { of people living with } \\
\text { Severe Mental Illness } \\
\text { (PLSMI) } \\
\text { Instrument: Oral } \\
\text { Assessment Guide (OAG) } \\
\text { Analysis: Sequential } \\
\text { analysis, Sequential t-test } \\
\text { analysis }\end{array}$ & $\begin{array}{l}\text { A range of hands-on and } \\
\text { practical care provided by } \\
\text { PLSMI caregivers, } \\
\text { emotional family dynamics, } \\
\text { and the social and cultural } \\
\text { context of care. Family care } \\
\text { gives roles that are } \\
\text { multidimensional, } \\
\text { challenging, and changing. } \\
\text { Family support can be a } \\
\text { major resource and an active } \\
\text { agent in mental health } \\
\text { recovery for PLSMI in } \\
\text { Uganda. Implementing } \\
\text { practical family-oriented } \\
\text { mental health interventions } \\
\text { requires culturally conscious } \\
\text { practice, based on an } \\
\text { understanding of dynamic } \\
\text { family relationships, a } \\
\text { cultural understanding of } \\
\text { mental illness. }\end{array}$ \\
\hline 19 & $\begin{array}{l}\text { Short term effects of } \\
\text { brief need based } \\
\text { psychoeducation on } \\
\text { knowledge, self-stigma, } \\
\text { and burden among } \\
\text { siblings of persons with } \\
\text { schizophrenia: } \\
\text { prospective controlled } \\
\text { trial. }\end{array}$ & $\begin{array}{l}\text { Design: prospective } \\
\text { controlled open-label trial } \\
\text { Sample: } 80 \text { siblings } \\
\text { Variable: tested the short- } \\
\text { term effects of brief needs- } \\
\text { based psychoeducation on } \\
\text { knowledge, self-stigma, } \\
\text { and burden among } \\
\text { schizophrenic siblings } \\
\text { Instrument: }\end{array}$ & $\begin{array}{l}\text { There was a significant } \\
\text { effect of group } \times \text { time } \\
\text { interaction on knowledge }(\mathrm{F} \\
=8.71 ; \mathrm{p}<0.01 ; \mathrm{p} 2=0.14) \\
\text { and self-stigma scores }(\mathrm{F}= \\
14.47 ; \mathrm{p}<0.001 ; \mathrm{p} 2= \\
0.21) \text { where the brief } \\
\text { psychoeducation group } \\
\text { showed a significant } \\
\text { increase in knowledge and a }\end{array}$ \\
\hline
\end{tabular}




\begin{tabular}{|c|c|c|}
\hline & $\begin{array}{l}\text { International } \\
\text { Neuropsychiatric } \\
\text { Interview- (MINI), } \\
\text { Structured Interview } \\
\text { for Prodromal Syndromes } \\
\text { (SIPS), Assessment of } \\
\text { Positive Symptoms } \\
\text { (SAPS), Scale for the } \\
\text { Assessment of Negative } \\
\text { Symptoms (SANS), The } \\
\text { Knowledge about } \\
\text { Schizophrenia Interview } \\
\text { (KASI), Aliate stigma } \\
\text { scale (self-stigma scale), } \\
\text { Burden assessment } \\
\text { schedule (BAS), } \\
\text { Analysis: RM-ANCOVA }\end{array}$ & $\begin{array}{l}\text { reduction in self- } \\
\text { stigmatization needs-based } \\
\text { psychoeducation brief could } \\
\text { increase knowledge about } \\
\text { the disease and reduce self- } \\
\text { stigma }\end{array}$ \\
\hline $\begin{array}{l}\text { 20. Risk factors associated } \\
\text { with the family care of } \\
\text { people with serious } \\
\text { mental illness. }\end{array}$ & $\begin{array}{l}\text { Design: cross-sectional } \\
\text { Sample: } 417 \text { families } \\
\text { Variables: analyze } \\
\text { variables related to family } \\
\text { care of people diagnosed } \\
\text { with serious mental illness } \\
\text { Instruments: } \\
\text { demographic } \\
\text { questionnaire and Zarit } \\
\text { Burden Interview } \\
\text { Analysis: t test, Pearson } \\
\text { correlation and variance } \\
\text { analysis, multiple linear } \\
\text { regression }\end{array}$ & $\begin{array}{l}\text { There was a significant } \\
\text { relationship between the } \\
\text { socio-demographic and } \\
\text { clinical variables of } \\
\text { caregivers and patients and } \\
\text { the perceived burden of } \\
\text { caregivers. Formal and } \\
\text { informal social support } \\
\text { stand out as protective } \\
\text { factors against the } \\
\text { consequences of the impact } \\
\text { of illness on primary } \\
\text { caregivers. Family } \\
\text { psychoeducation programs } \\
\text { should be created, } \\
\text { implemented and evaluated } \\
\text { in all mental health services } \\
\text { to strengthen training in } \\
\text { mental health issues and } \\
\text { provide support and } \\
\text { assessment to caregivers to } \\
\text { ease their burden. }\end{array}$ \\
\hline
\end{tabular}

\section{DISCUSSION}

\section{The Burden of Family Care}

In many societies, family members are now the primary caregivers of mental health patients, taking on responsibilities traditionally under the overview of hospital and medical professionals. The impact of this shift on the family is high, has an emotional and economic burden. ${ }^{15}$ Families with schizophrenia experience the strongest stressors on the burden of care borne, in addition to stigma and the frequency of patient relapse. ${ }^{3}$ This is reinforced by the high household care burden for people living with schizophrenia in low-income settings. ${ }^{16}$ It was also found that caregiver of people with psychosis had worse mental health than non- 
caregivers. Single caregivers and those who spend more than 35 hours per week caring are found to be most at risk for poor mental health. ${ }^{10}$ Basically, the condition of schizophrenia has an impact on the burden on the family in caring for and it is proven that there is a significant relationship between socio-demographic and clinical variables of caregivers and patients and the burden felt by caregivers. ${ }^{23}$

The burden of treatment costs felt by the family is due to the length of recovery at the service provider and the frequency of recurrence, resulting in shorter re-admission times. The findings explain that low income, stigma, and quality of family care are critical determinants of health-related quality of life, so efforts to improve family life satisfaction are focused on reducing stigma, increasing family income and strengthening quality-centered care family. ${ }^{17}$

\section{Family Psychoeducation}

Mental health professionals can provide family support as a result of the burden of caring for schizophrenia by reducing the burden, family therapy, education and psychological support should be provided to families. ${ }^{9}$ This is reinforced by the finding that there is a need to provide support for caregivers by a mental health care delivery service system. ${ }^{1}$ Family psychoeducation can be an intervention that is considered to reduce the burden of family care, this is reinforced that Schizophrenic Patients who receive Family psychoeducation show a significant effect of treatment because they have a greater reduction in psychotic symptoms (PANSS), improvement in social functioning (SFQ), quality of life. life (QoL), and attitudes towards drugs (DAI). ${ }^{11}$ The psychosocial burden experienced by the family can also bring up emotional expressions that can be a barrier factor for care between patients and families, nursing interventions carried out to minimize emotional expressions have been widely studied and the majority recommend providing psychoeducation and the results are proven to reduce family emotional expressions. ${ }^{18}$

Mental health care professionals should involve all family members, including siblings, in the treatment plan for people with schizophrenia, and provide appropriate psychoeducation for all family members to reduce not only current parenting tensions and stress, but also anxiety about future care. ${ }^{14}$ The need for psychoeducation involving siblings in the management of schizophrenia is also reinforced by the finding that brief needs-based psychoeducation can increase knowledge about the disease and reduce self-stigma. ${ }^{22}$. Families will adapt and develop to respond to members who experience schizophrenia, family interventions that can be provided usually include psychoeducation, stress management, emotion, processing, assertive communication, cognitive reassessment, and structured problem solving proven to be effective in improving symptomatology, disease awareness, and levels of satisfaction. in patients and relatives. ${ }^{15}$

Components in psychoeducation in addition to family burden stress management also include family coping skills education in adapting to stressors in caring for families with schizophrenia, the results of the study explain that strengthening family coping resources (SFCR) This intervention can guide health professionals in implementing family-centered care programs to reduce stress. burden of caring for schizophrenic patients through family support in the efficient care of these patients. ${ }^{20}$. This is reinforced by the finding that there is a relationship between knowledge, perception, attitude, and family support and independence in treating hebephrenic schizophrenia. ${ }^{7}$ In addition, good support from health professionals and social services is needed to help family caregivers cope well with their stressors. ${ }^{8}$

Another approach used to reduce the burden experienced by families in caring for schizophrenia is to develop family resilience, which can increase the capability of families in caring for schizophrenia. The model helps families through stress management to reduce the burden of parenting and labeling sufferers. have resilience, use sources of strength and develop according to family functions to treat schizophrenia. ${ }^{19}$ The results of another study 
stated that strengthening family coping resources (SFCR) can guide service providers on how to implement family-centered care programs to reduce the burden of caring for schizophrenic patients through family support in efficient care. ${ }^{20}$

Care providers in the community can involve the family in a variety of ways, such as providing psychoeducation, supporting the family's physical, emotional and social needs, and behavioral family assessment or family therapy. ${ }^{24}$ In addition, family psychoeducation programs should be created, implemented and evaluated in all mental health services to strengthen training in mental health issues and provide support and assessment to caregivers to ease their burden. ${ }^{23}$

\section{CONCLUSIONS}

Family psychoeducation is an intervention of family support reducing the burden of caregivers taking care of schizophrenia. Mental health professionals need to develop and conduct family psychoeducation training so that it can be implemented in services.

\section{REFERENCES}

1. Ebrahimi H, Seyedfatemi N, Namdar Areshtanab H, et al. Barriers to Family Caregivers' Coping With Patients With Severe Mental Illness in Iran. Qual Health Res. 2018;28(6):987-1001. doi:10.1177/1049732318758644

2. Bai XL, Luo ZC, Wang A, et al. Challenge of parents caring for children or adolescents with early-stage schizophrenia in China: A qualitative study. Perspect Psychiatr Care. 2020;56(4):777-784. doi:10.1111/ppc.12492

3. Fitryasari R, Nursalam N, Yusuf A, Hargono R, Chan C-M. Predictors of Family Stress in Taking Care of Patients with Schizophrenia. J Ners. 2018;13(1):72. doi:10.20473/jn.v13i1.7762

4. World Health Organization. Scizophrenia. Published 2019. Accessed September 21, 2021. https://www.who.int/news-room/fact-sheets/detail/schizophrenia

5. Hsiao CY, Lu HL, Tsai YF. Caregiver burden and health-related quality of life among primary family caregivers of individuals with schizophrenia: a cross-sectional study. Qual Life Res. 2020;29(10):2745-2757. doi:10.1007/s11136-020-02518-1

6. Kementerian Kesehatan Republik Indonesia. Laporan Nasional Riset Kesehatan Dasar. Kementeri Kesehat RI. Published online 2018:1-582.

7. Herlin Ferliana et. a. Determinants of family independence in caring for hebephrenicschizophrenia patients. J Public health Res. 2020;9(1828):149-151.

8. Janah M, Hargiana G. Levels of stress and coping strategies in family caregivers who treat schizophrenic patients with risk of violent behavior. J Public health Res. 2021;10. doi:10.4081/jphr.2021.2404

9. Attepe Özden S, Tuncay T. The experiences of Turkish families caring for individuals with Schizophrenia: A qualitative inquiry. Int J Soc Psychiatry. 2018;64(5):497-505. doi:10.1177/0020764018779090

10. Sin J, Elkes J, Batchelor R, et al. Mental health and caregiving experiences of family carers supporting people with psychosis. Epidemiol Psychiatr Sci. 2021;30. doi:10.1017/S2045796020001067

11. Rami H, Hussien H, Rabie M, Sabry W, Missiry M El, Ghamry R El. Evaluating the effectiveness of a culturally adapted behavioral family psycho-educational program for Egyptian patients with schizophrenia. Transcult Psychiatry. 2018;55(5):601-622. doi:10.1177/1363461518782520

12. Rose LE, Mallinson RK, Walton-Moss B. Barriers to family care in psychiatric settings. J Nurs Scholarsh. 2004;36(1):39-47. doi:10.1111/j.1547-5069.2004.04009.x

13. Alugo T, Malone H, Sheehan A, Coyne I, Lawlor A, McNicholas F. Development of a 
medRxiv preprint doi: https://doi.org/10.1101/2022.01.11.22268923; this version posted January 14, 2022. The copyright holder for this preprint (which was not certified by peer review) is the author/funder, who has granted medRxiv a license to display the preprint in perpetuity.

22q11DS psycho-educational programme: exploration of the views, concerns and educational needs of parents caring for children or adolescents with 22q11DS in relation to mental health issues. Child Care Health Dev. 2017;43(4):527-535. doi:10.1111/cch.12457

14. Yang CI, Hsieh MY, Lee LH, Chen SL. Experiences of caring for a sibling with schizophrenia in a Chinese context: A neglected issue. Int J Ment Health Nurs. 2017;26(4):409-417. doi:10.1111/inm.12269

15. Caqueo-Urízar A, Rus-Calafell M, Craig TKJ, et al. Schizophrenia: Impact on Family Dynamics. Curr Psychiatry Rep. 2017;19(1). doi:10.1007/s11920-017-0756-z

16. Opoku-Boateng YN, Kretchy IA, Aryeetey GC, et al. Economic cost and quality of life of family caregivers of schizophrenic patients attending psychiatric hospitals in Ghana. BMC Health Serv Res. 2017;17(Suppl 2). doi:10.1186/s12913-017-2642-0

17. Chiu-Yueh Hsiao et.al. Living with schizophrenia: Health related quality of life among primary family caregivers. J Clin Nurs. 2017;26(23-24):5151-5159.

18. Mubin MF, Ignatius I, Soewadi S, Sakti H, Erawati E. The influence of psychoeducation on family's emotional expressions in caring patients with paranoid schizophrenia. Rawal Med J. 2020;45(4):915-919.

19. Fitryasari R, Nursalam N, Yusuf A, Hargono R, Lin ECL, Tristiana RD. Development of a family resiliency model to care of patients with schizophrenia. Scand J Caring Sci. 2021;35(2):642-649. doi:10.1111/scs.12886

20. Kazemian S, Zarei N, Esmaeily M. Effect of strengthening family coping resources on emotion regulation of family caregivers of patients with schizophrenia. Evid Based Care J. 2020;10(2):7-17. doi:10.22038/ebcj.2020.44754.2211

21. Verity F, Turiho A, Mutamba BB, Cappo D. Family care for persons with severe mental illness: experiences and perspectives of caregivers in Uganda. Int J Ment Health Syst. 2021;15(1):1-10. doi:10.1186/s13033-021-00470-2

22. Amaresha AC, Kalmady SV, Joseph B, et al. Short term effects of brief need based psychoeducation on knowledge, self-stigma, and burden among siblings of persons with schizophrenia: A prospective controlled trial. Asian J Psychiatr. 2018;32(October 2017):59-66. doi:10.1016/j.ajp.2017.11.030

23. Carbonell Á, Navarro-Pérez JJ, Mestre MV. Risk factors associated with the family care of people with serious mental illness. Med Oral Patol Oral y Cir Bucal. 2019;24(4):e438-e443. doi:10.4317/medoral.23133

24. Ong HS, Fernandez PA, Lim HK. Family engagement as part of managing patients with mental illness in primary care. Singapore Med J. 2021;62(5):213-219. doi:10.11622/smedj.2021057 